Redaksionele kommentaar

\title{
Hulde aan prof. Pieter de Klerk
}

Prof. Pieter de Klerk (65), vakgroephoof Geskiedenis in die fakulteit Lettere op die Vaaldriehoekkampus van die Noordwes-Universiteit (NWU), tree aan die einde van Desember 2011 af.

'n Gedeelte van hierdie uitgawe van TD Die Joernaal vir Transdissiplinêre Navorsing in SuiderAfrika, word gebruik as ' $n$ huldigingsbundel vir 'n kollega wat diep akademiese spore in NWU, veral die Vaaldriehoekkampus, getrap het. Prof. De Klerk het oor 'n tydperk van sowat 44 jaar baie ervaar en baie mense leer ken. Hy het ook bekendheid verwerf. Al het hy in beskeidenheid en soms bykans onopvallend, sy weg deur die wandelgange en lokale van die universiteit gebaan, was almal bewus van sy liefde vir kennis en meer insig. As akademikus het hy ' $n$ invloed op die intellektuele vorming van menige student op die voor- en nagraadse vlak gehad.

Hy het ook 'n geestelik verrykende invloed op kollegas uitgeoefen. Die redaksie van TD het vakgenote in geskiedenis aan ander universiteite in Suid-Afrika gevra om bydraes te lewer. Hulle artikels werp lig op terreine van die Suid-Afrikaanse geskiedenis waarin prof. De Klerk 'n lewendige belangstelling het. Veral sy interpretatiewe artikels oor die Suid-Afrikaanse geskiedenis, vanuit die perspektief van die historiografie is ' $n$ aanduiding van die breë spektrum van sy diepte-kennis. Hy het voortdurend op die voorpunt van nuwe tendense in die Suid-Afrikaanse geskiedskrywing gebly. As ewekniebeoordelaar van akademiese artikels en aktiewe medewerker op die redaksie van verskeie tydskrifte, onder meer Historia, die amptelike tydskrif van die Historiese Genootskap van Suid-Afrika, het hy waardevolle insette gelewer.

Vir die doeleindes van hierdie bundel is werk gemaak om kollegas in die Skool vir Basiese Wetenskappe aan die NWU Vaal te kry om bydraes te lewer. Ook in hul werk wat hier aangebied word, het prof. De Klerk, regstreeks en onregstreeks, ' $n$ waardevolle bydrae gelewer.

Sedert die skoolkonsep in 1998 aan die NWU ingevoer is, het prof. De Klerk as akademiese en administratiewe leier ' $n$ belangrike rol gespeel. Daar moes opnuut gedink word oor die wyse waarop akademiese bestuur moes plaasvind in 'n stelsel waar departemente in vakgroepe omgeskakel is. Die 'verplatting' van strukture in ' $n$ skoolsisteem moes daartoe meewerk om in 'n groter mate die integrasie van dissiplines te bevorder.

Menige gesprek het soggens in die teekamer van die Skool vir Basiese Wetenskappe oor die jare plaasgevind wat prikkelende idees by kollegas tuisgebring het. Prof. De Klerk was 'n belangrike deelnemer in die gesprekke. Hy het voortdurend 'n pro-aktiewe rol gespeel om die skooldirekteur (tans prof. TC Rabali) van goeie raad te bedien. Ook het hy in die fakulteit op menige komitee gedien en waardevolle insette gelewer. Sy doelwit was voortdurend om doeltreffendheid in die stelsel, asook goeie akademiese standaarde na te streef.

Die dissiplines wat tans (2011) in die Skool vir Basiese Wetenskappe beoefen word, sluit in Td Die Joernaal vir Transdissiplinêre Navorsing in Suider-Afrika, 7(2) Desember 2011, pp. iii - viii. 
Geskiedenis, Bybelkunde, Filosofie, Openbare Bestuur en Administrasie asook Politieke Wetenskap. Ofskoon prof. De Klerk verkies het om homself met sy geliefde vak, geskiedenis, besig te hou, het hy graag aan akademiese gesprekke met kollegas in ander dissiplines deelgeneem. Sy skerpheid van intellek en die vermoë om indringend tot die essensie van wetenskaplike denke te kom, het 'n waardevolle rol in die skool gespeel.

Oor die jare het die interaksie tussen kollegas vanuit bepaalde dissiplinêre perspektiewe ' $n$ invloed op die belewenis van die daaglike akademiese werklikheid uitgeoefen. Vanselfsprekend het die omstandighede ook hul navorsingswerk beïnvloed. Die verskeidenheid van artikels wat in die bundel opgeneem word, dui op die spektrum van denke en idees wat in ' $n$ skool van bykans 20 lede kan sirkuleer. Prof. De Klerk het as akademikus aan menige colloquium en navorsingsgesprek van die Skool vir Basiese Wetenskappe aktief deelgeneem. Daardeur het hy kollegas in die strewe na beter navorsingwerk ' $n$ waardevolle diens bewys. Hul bydraes in hierdie bundel is 'n blyk van dankbaarheid. 


\section{Pieter de Klerk - Beknopte curriculum vitae}

1. PERSOONLIKE BESONDERHEDE

Van: De Klerk

Voorname: Pieter

Geboortedatum: 1946-04-02

1.1 LOOPBAANGESKIEDENIS

$\begin{array}{lll}\text { Werkgewer } & \text { Posbenaming } & \text { Dienstydperk } \\ \text { PU vir CHO (Potch) } & \text { Junior Lektor } & 1968-1970 \\ \text { PU vir CHO } & \text { Lektor 1971 - } & 1972 \\ \text { PU vir CHO } & \text { Senior Lektor } & 1973-1982 \\ \text { PU vir CHO(VDK) } & \text { Medeprofessor } & 1983-1991 \\ \text { PU vir CHO/NWU } & \text { Professor } & 1992-\text { tans }\end{array}$

\section{AKADEMIESE EN PROFESSIONELE KWALIFIKASIES}

2.1 SKOOLLOOPBAAN

Naam van Hoërskool: D.F. Malan, Bellville

Matriekjaar: 1963

\subsection{TERSIÊRE KWALIFIKASIES}

Kwalifikasie Prof./Akad. Inrigting Jaar behaal Rigting

\begin{tabular}{|c|c|c|c|}
\hline B.A. & A & PU vir CHO 1966 & Gesk. en Staatsleer \\
\hline Honns. B.A. & A & PU vir CHO 1967 & Geskiedenis \\
\hline M.A. & $A$ & PU vir CHO 1969 & Geskiedenis \\
\hline D.Litt. & A & PU vir CHO 1971 & Geskiedenis \\
\hline B.Ed. & A & PU vir CHO 1973 & \\
\hline D.Ed. & $A$ & PU vir CHO 1975 & Tersiêre Onderwys \\
\hline
\end{tabular}

\section{PUBLIKASIES}

3.1 BOEKE (GESPESIALISEERDE WERKE)

1. De Klerk, P. 1973. Geskiedenisvergelyking: die gebruik van vergelykende metodes wat gerig is op generalisasie in die geskiedkunde. Pro Rege, Potchefstroom. (RGNpublikasiereeks, nr. 23). 237 bls.

2. De Klerk, P. 1975. Blywende kolonisasie? 'n Vergelyking van 'n aantal kolonisasies in die geskiedenis. PU vir CHO (Wetenskaplike bydraes, A15). 242 bls.

3. De Klerk, P. 1977. Die opvoedingstaak van die vak Geskiedenis, in besonder aan die universiteit. De Jong, Braamfontein, (RGN-publikasiereeks, nr. 59). 263 bls. 
4. De Klerk, P. 1981. Geskiedenis as kultuurontwikkeling: aspekte van die teorie en filosofie van Geskiedenis. Butterworths, Durban. 175 bls. (Herdruk 1988).

5. De Klerk, P. Het Algemeen-Nederlands Verbond in Zuid-Afrika (1895-2008). Kaapstad/Den Haag, ANV, 2008

\subsection{UNIVERSITEITSHANDBOEKE}

1. De Klerk, P, Pretorius, Z.L., Ingram-Barrish, J.R. 1977. Die opkoms van Europa. 'n Inleiding tot die Westerse beskawingsgeskiedenis vanaf die 15 de eeu tot 1815 . Butterworths, Durban, 439 bls. (Herdruk 1985.)

2. Kapp, P.H., Moll, J.C., De Jongh, P.S., de Klerk, P., Bergh, J.S. 1984. Geskiedenis van die Westerse Beskawing, Deel III, Van Rewolusie tot Wêreldoorlog. HAUM, Pretoria. 423 bls.

3. Kapp, P.H., Moll, J.C., De Jongh, P.S., de Klerk, P., Van der Merwe, W. en Grundlingh, L.W.F. 1989. Geskiedenis van die Westerse Beskawing, Deel III, Tussen twee Wêreldoorloë. HAUM, Pretoria. 349 bls.

3.3 ARTIKELS IN VAKTYDSKRIFTE (Vanaf 1984 subsidiedraende tydskrifte)

1. De Klerk, P. 1973. Die beginsels van geskiedskrywing. Perspektief, Vol. 12(4): 1315, Sept.

2. De Klerk, P. 1974. Aims and methods of historical comparison. Koers, Vol. 39(5 en 6): $289-310$.

3. De Klerk, P. 1974. Relevant history. A Christian view on the task of the historian provides an answer to the present crisis in historical study. Koers, Vol. 39(5 en 6): $267-288.4$.

4. De Klerk, P. 1974. Vergelyking in die bestudering van geskiedenis. Suid-Afrikaanse Historiese Joernaal, vol. 6: 88 - 103, Nov.5.

5. De Klerk, P. 1975. Die vorming van historiese perspektief as algemene opvoedingstaak van die universiteit. Bulletin van die Suid-Afrikaanse vereniging vir die bevordering van Christelike wetenskap, Vol. 45: 3 - 31, Jul.6.

6. De Klerk, P. 1983. Geskiedenis en staatsleer. Historia, Vol. 28(1): 1 - 10 Mei.

7. De Klerk, P. 1988. Vormverandering van kolonialisme in die geskiedenis. Koers, Vol. 53(1): 121 - 146.8.

8. De Klerk, P. 1988. Kolonialisme as historiese proses. Koers, Vol. 53(4): 537 - 567.

9. De Klerk, P. 1989. Afrikanerdenkers en die beginsels van die Ossewa-Brandwag. Joernaal vir eietydse geskiedenis, Vol. 14(1): 43 - 81, Jun..

10. De Klerk, P. 1989. Die Ossewa-Brandwag se ideaal van 'n nuwe samelewingsorde in Suid-Afrika. Joernaal vir eietydse geskiedenis, Vol. 14(2): 90 - 131, Des.

11. De Klerk, P. 1989. Die rol van kolonialisme in historiese ontwikkeling. Koers, Vol. 54(3): $249-271$.

12. De Klerk, P. 1989. Twee perspektiewe op die Suid-Afrikaanse historiografie. Contree, Vol. 25: 29 - 31. 
13. De Klerk, P. 1990. Die Walvisbaai-enklawe: 'n koloniale oorblyfsel? Joernaal vir Eietydse Geskiedenis, Vol. 15(3): 72 - 90.

14. De Klerk, P. 1994. Van 'n Eurosentriese na 'n Afrosentriese Geskiedenis. Koers, Vol. 59(1): 53 - 68.

15. De Klerk, P. 1994. Die plek van kultuurgeskiedenis in algemene historiese oorsigwerke - 'n vergelykende ondersoek. Suid-Afrikaanse Tydskrif vir Kultuurgeskiedenis, Vol. 8(1): 31 - 34.

16. De Klerk, P. 1994. Die Algemeen-Nederlands Verbond en die Anglo-Boereoorlog (1899 - 1902). Suid-Afrikaanse Tydskrif vir Kultuurgeskiedenis, Vol. 8(2): 65 - 71.

17. De Klerk, P. 1996. Die Algemeen-Nederlands Verbond en Suid-Afrika, 1945 1995. Joernaal vir Eietydse Geskiedenis, Vol. 21(1): 68 - 87.

18. De Klerk, P. 1996. Nederlandse nasionalisme en Afrikanernasionalisme - 'n vergelyking. Koers, Vol. 61(3): 323 - 344.

19. De Klerk, P. 1997. Politieke koersaanduiding in Koers, 1933 - 1961. Koers, Vol. 62(1): $45-76$.

20. De Klerk, P. 1997. Die Algemeen-Nederlands Verbond en Suid-Afrika, 1906 1940. Suid-Afrikaanse Tydskrif vir Kultuurgeskiedenis, Vol. 11(1): 109 - 122.

21. De Klerk, P. 1998. Afrikaners en Nederlanders: stamverwante? Koers, 63(4): 295312.

22. De Klerk, P. 1999. Die Suid-Afrikaanse geskiedenis in vergelykende perspektief - 'n metodologiese ondersoek. Historia, Vol. 44(2): 287-306.

23. De Klerk, P. 2000. Die tydskrif Woord en Daad en die apartheidsbeleid, 1954-1966. Joernaal vir Eietydse Geskiedenis, Vol. 25(1): 72-8.

24. De Klerk, P. 2001. Van Afrikaans tot multikultureel -die Vaaldriehoekkampus van die PU vir CHO, 1966-2000. Suid-Afrikaanse Tydskrif vir Kultuurgeskiedenis, Vol. 15(1): 34-49.

25. De Klerk, P. 2001. Afskeid van apartheid - die politieke koers van die tydskrif Woord en Daad in die periode 1967-1990. Joernaal vir Eietydse Geskiedenis, Vol. 26(2): 3457

26. De Klerk, P. 2001. Die probleemstelling - noodsaaklike beginpunt vir historiese navorsing? Historia, Vol. 46(2): 405-425.

27. De Klerk, P. 2002. 1652 - die beginpunt van kolonialisme in Suid-Afrika? Historia, Vol. 47(2):739-764.

28. De Klerk, P. 2003. D.W. Krüger as skrywer van eietydse geskiedenis. Joernaal vir Eietydse Geskiedenis, Vol. 28(3):72-91.

29. De Klerk, P. 2004. Die bydrae van J.S. du Plessis (1919-1990) tot die geskiedskrywing, Historia, Vol. 49(2):187-202.

30. De Klerk, P. 2005. Die oorsprong van die Afrikaanse republikeinse tradisie - 'n historiografiese verkenning. Tydskrif vir Geesteswetenskappe, Vol. 45(2):218-231.

31. De Klerk, P. 2005. Die verband tussen apartheid en Nasionaal-Sosialisme. Joernaal 
vir Eietydse Geskiedenis, Vol. 30(2): 1-18.

32. De Klerk, P. 2005. Suid-Afrika binne wêreldhistoriese konteks - 'n ondersoek na oorsigwerke oor die Suid-Afrikaanse geskiedenis. Historia, Vol. 50(2):261-286.

33. De Klerk, P. 2006. Die politieke beskouinge van Paul Kruger - interpretasies oor 'n tydperk van 125 jaart. Tydskrif vir Geesteswetenskappe, Vol. 46(23):171-183.

34. De Klerk, P. 2007. Die akkulturasie van die Khoikhoi en die slawe in die Kaapkolonie (1652-1910). Suid-Afrikaanse Tydskrif vir Kultuurgeskiedenis, Vol. 21(1):1-21.

35. De Klerk, P. en Haarhoff, J. 2007. Die bydrae van Karel Schoeman tot geskiedskrywing oor die kaapkolonie. Historia, Vol. 52(2):125-149.

36. De Klerk, P. 2008. Taal, kultuur en ontspanning: die rol van die AlgemeenNederlands Verbond in Kaapstad, 1995-2008. New Contree, Vol. 55: 67-92..

37. De Klerk, P. 2008. F.A. van Jaarsveld se Die ontwaking van die Afrikaanse nasionale bewussyn na vyftig jaar. Tydskrif vir Geesteswetenskappe, Vol. 48(3): 339-356.

38. De Klerk, P. 2009. Die stigting van die Kaapkolonie in die Nederlandse geskiedskrywing. Historia, Vol. 54(2): 178-196.

39. De Klerk, P. 2009. Streeksgeskiedskrywing en koloniale verhoudinge: die WesKaapse platteland en die Karoo. New Contree, Vol. 58: 1-36.

40. De Klerk, P. 2009. Was die Groot Trek werklik groot? 'n Historiografiese ondersoek na die gevolge en betekenis van die Groot Trek. Tydskrif vir Geesteswertenskappe, Vol. 49(4): 658-673.

41. De Klerk, P. 2010. Integrasieprosesse in die vroeë Kaapkolonie (1652-1795) binne vergelykende konteks - 'n historiografiese studie. New Contree, Vol, 59: 1-28.

42. De Klerk, P. 2011. Die periodisering van die Suid-Afrikaanse geskiedenis in resente oorsigwerke. Historia, Vol. 56(1): 138-152..

\subsection{BYDRAES IN WETENSKAPLIKE VERSAMELWERKE}

1. De Klerk, P. 1974. Reformasie en revolusie in die geskiedenis. In: PU vir CHO (IBC), Reformasie en revolusie. Potchefstroom. B1s. 23 - 36.

2. De Klerk, P. 1975. Die Indiese Oseaan in die wêreld politiek - 'n historiese oorsig. In: PU vir CHO (SIP), Die Indiese Oseaan in die wêreldpolitiek, Potchefstroom. B1s. 11-41.

3. De Klerk, P. 1976. Geskiedeniswetenskap. In: P. de Klerk (red.), Die geskiedenis in die wetenskap. PU vir CHO, Potchefstroom, Bls. 1 - 14.

4. De Klerk, P. 1976. Die Midde-Ooste in die wêreldpolitiek - 'n historiese verkenning. In: $\mathrm{PU}$ vir $\mathrm{CHO}$ (SIP), Die Midde-Ooste, kookpot van die wêreldpolitiek, Potchefstroom. B1s. 9 - 32.

5. De Klerk, P. 1977. P.D.C. Grobler. In: D.W. Krüger en C.J. Beyers (reds.), SuidAfrikaanse biografiese woordeboek, Deel III. Kaapstaad, Tafelberg. B1s. 365 - 367.

6. De Klerk, P. 1980. Hoofmomente in die Amerikaanse geskiedenis. In: PU vir CHO (SIP), Die VSA in die wêreldpolitiek. Potchefstroom, Bls. 1 - 23. 
7. De Klerk, P. 1984. Afrika deur ideologieë geteister. In: PU vir CHO (IRS), Ideologiese stryd in Suider-Afrika. Potchefstroom. B1s. 41 - 50.

8. De Klerk, P. 1985. Fasette van ontwikkelingsproblematiek in Christelike perspektief. In: PU vir CHO, Mens en samelewing: 'n bundel opstelle uit die Fakulteit Lettere en Wysbegeerte van die PU vir CHO. Potchefstroom. B1s. 56 - 68.

9. De Klerk, P. 1987. Die Ooste en Afrika: 'n historiese oorsig. In: C.J. Maritz (red.), Afrika tussen die Ooste en die Weste. Potchefstroom, PU vir CHO. Bls. 1 - 13.

10. De Klerk, P. 1987. Paradigmas in die geskiedeniswetenskap. In: PU vir CHO, Paradigmas in die wetenskappe, 'n Christelike perspektief. Potchefstroom. Bls. 46 50.

11. De Klerk, P. 1991. Die ideologie van die Ossewa-Brandwag. In: Van der Schyff, P.F. (red.) Die Ossewa-Brandwag: vuurtjie in droeë gras. Potchefstroom, PU vir CHO. B1s. 292 - 331.

12. De Klerk, P. 1992. Die eenheid van die geskiedenis. Wetenskaplike bydraes van die PU vir CHO. Reeks H: Intreeredes, nr. 128.

13. De Klerk, $\mathrm{P}$ en Tempelhoff, J. 2006. Die ontwikkeling van die universiteitswese in besonder in Suid-Afrika. In: Van Eeden, E.S. (red.) 'In u lig': Die PU vir CHO van selfstandigwording tot samesmelting, 1951-2004. Potchefstroom, NoordwesUniversiteit. B1s. 19-36.

14. De Klerk, P. en Du Pisani, K. 2006. Ontwikkeling op onderriggebied. In: Van Eeden, E.S. (red.) 'In u lig': Die PU vir CHO van selfstandigwording tot samesmelting, 1951-2004.. Potchefstroom, Noordwes-Universiteit. B1s. 85-140.

15. De Klerk, P. en Möller, P. 2006. Ontstaan en ontwikkeling van die Vaaldriehoekkampus. In: Van Eeden, E.S. (red.) 'In u lig': Die PU vir CHO van selfstandigwording tot samesmelting, 1951-2004. Potchefstroom, NoordwesUniversiteit. B1s. 443-484.

\subsection{REDIGERING VAN VERSAMELWERK}

1. P. de Klerk (red.). 1976. Die geskiedenis in die wetenskap. Potchefstroom, PU vir CHO (Wetenskaplike bydraes, reeks A, nr. 22). 142 bls.

\subsection{ANDER PUBLIKASIES}

1. Populêr-wetenskaplike artikels. Sowat 35 artikels het vanaf 1966 in die volgende tydskrifte verskyn. Die Besembos, Loog, Woord en Daad, Nuus oor Afrika, Die wêreld in oënskou, IRS-studiestukke, Gister en Vandag, Oënskou, Orientation, Handhaaf.

2. Boekresensensies. Ongeveer 70 boekresensies het verskyn in die volgende tydskrifte: Historia, Suid-Afrikaanse Historiese Joernaal, Kleio, Koers, Gister en Vandag, Woord en Daad, The Journal for Transdisciplinary Research in Southern Africa, Tydskrif vir Geesteswetenskappe. 


\section{ONGEPUBLISEERDE VERHANDELINGE EN VERSLAE}

\subsection{VERHANDELINGE}

1. De Klerk, P. 1969. Die geskiedskrywing oor Paul Kruger. M.A.-verhandeling, PU vir CHO. 257 bls.

2. De Klerk, P. 1970. Geskiedenisvergelyking: die gebruik van vergelykende metodes wat gerig is op generalisasie in die geskiedkunde. D.Litt.-proefskrif, $\mathrm{PU}$ vir $\mathrm{CHO}$, 341 bls., (Gepubliseer in verkorte vorm, aangedui in 3.1).

3. De Klerk, P. 1974. Die uitvoering van die universiteitstaak in die vak Geskiedenis. D.Ed.-proefskrif PU vir CHO. 487 bls. (Gepubliseer in verkorte vorm, aangedui in 3.1).

4.2 VERSLAE

1. Van der Schyff, P.F., Badenhorst, J.J., De Klerk, P., Fourie, L.M. en Prinsloo, P.J.J. 1984. Geskiedenis van die Ossewa-Brandwag. PU vir CHO (Dept. Geskiedenis). 460 bls.

2. De Klerk, P. 1981. Die ideologie van die Ossewa-Brandwag - subverslag. PU vir CHO (Dept. Geskiedenis). 136 bls.

\section{AKADEMIESE AKTIWITEITE}

5.1 EKSTERNE EKSAMINATORSKAPPE

Eksterne eksiminator vir voorgraadse en nagraadse werk, insluitende skripsies, verhandelinge en proefskrifte, vir: Randse Afrikaanse Universiteit (tans Universiteit van Johannesburg); Universiteit van Suid-Afrika; Universiteit van Namibië; Universiteit van die Noorde (tans Universiteit van Limpopo); Universiteit van Stellenbosch; en Universiteit van Zululand.

5.2 ONDERRIGERVARING

1. PU vir CHO./NWU Doseer vanaf 1967 B.A. Geskiedenis I, II, III feitlik alle afdelings, in besonder Wêreldgeskiedenis.

2. 1969 - tans. Honns. B.A. Geskiedenis, Teorie, Historiografie, Die Reformasie, Kolonialisme.

3. 1969 - 1975. M.A. Filosofie van Geskiedenis.

4. 1979 - 1981. Wetenskapsleer, Geskiedenisfilosofie.

5. 2000-2003 Wetenskapsleer, Kultuurfilosofie.

5.3 STUDIELEIDING - Ms EN Ds (AFGEHANDEL)

Promotor, hulppromotor en studieleier vir ses proefsktifte, verhandelinge en skripsie 


\section{LIDMAATSKAP EN DEELNAME AAN VERENIGINGS EN RADE}

\section{$6.1 \quad$ KOMMISSIES, KOMITEES, FAKULTEITSRADE}

1. Senaat $1992-2007$

2. $\quad$ Fakulteitsraad Lettere en Wysbegeerte. 1983 - 1991. Lid.

3. Fakulteitskomitee Lettere en Wysbegeerte (Vaaldriehoekkampus). 1983 -1991. Lid. Ook lid van die volgende subkomitees: Eksamenkomitee, Versoekekomitee, Regulasie-, jaarboek- en roosterkomitee, dagbestuur.

4. Interfakultêre Akademiese Raad/Fakulteitsraad Vaaldriehoek, Fakulteitsraad Geesteswetenskappe, 1992 - tans. Lid. Ook lid van die volgende fakulteritskomitees: Navorsingskomitee, Eksamenkomitee, Rooster- en Jaarboekkomitee.

5. Beplanningskomitee, Vaaldriehoekkampus. 1992 - 1998. Lid.

6. Beheerraad Instituut vir SA Politiek. 1977 - 1882. Lid.

7. Beheerraad Instituut vir Reformatoriese studie. 1984 - 1987. Lid.

8. Departementele verteenwoordiger, Vaaldriehoekkampus, Departement Geskiedenis. 1983 - 1991.

9. Hoof, Departement Geskiedenis (VDK). 1992 - 1998.

10. Vakvoorsitter, Geskiedenis (VDK). 1999-tans

6.2 REDAKSIES

1. Loog. 1971 - 1974. Redakteur.

2. $\quad$ Woord en Daad. 1974 - 1984. Redaksielid.

3. Gister en Vandag. Tydskrif vir Geskiedenisonderrig. 1984 - tans. Redaksielid.

4. Suid-Afrikaanse Historiese Joernaal. 1991 - 2003. Redaksielid.

5. Historia. Redaksielid, 1999-2003, mederedakteur 2006-2010.

6. Keurder vir verskeie artikels in SA Historiese Joernaal, Joernaal vir Eietydse Geskiedenis, Koers, Tydskrif vir Geesteswetenskappe, SA Tydskrif vir Kultuurgeskiedenis, Historia, The Journal for Transdisciplinary Research in Southern Africa, Tydskrif vir Geesteswetenskappe, New Contree.

6.3 VAKVERENIGINGS

1. $\quad$ SA Historiese Vereniging. 1973 - 1975. Bestuurslid.

2. $\quad$ SA Historiese Vereniging. 1969 - tans. Lid.

3. SA Akademie vir Wetenskap en Kuns. 1978 - tans. Lid.

4. American Historical Society. 1988 - 1998. Lid.

5. International Society for the Comparative Study of Civilizations. 1988 - 2002. Lid. 
6. $\quad$ SA Vereniging vir Geskiedenisonderwys. 1987 -2002. Lid.

7. World History Association. 1990 - 2003. Lid.

8. $\quad$ SA Vereniging vir Kultuurgeskiedenis. 1996 - tans. Lid.

\section{TOEKENNINGS}

7.1 NAVORSINGSTOEKENNINGS

1. Ad hoc beurs. 1973. RGN.

2. Toekenning vir vakfilosofiese navorsing. 1979. PU vir CHO. Departement Wetenskapsleer.

\subsection{BEURSTOEKENNINGS}

1. Nasionale Beurs. $1969-1970$.

\subsection{PUBLIKASIETOEKENNINGS}

1. Publikasietoekenning. 1973. RGN (vir publikasie van boek aangedui in 3.1-1).

2. Publikasietoekenning. 1977. RGN (vir publikasie van boek aangedui in 3.1-3).

7.4 TOEKENNING VIR LEWERING VAN REFERAAT IN DIE BUITELAND

1. 1992. SWO.

2. 1994. SWO.

7.5 PRYSE

1. Erepenning vir Geskiedenisbevordering van die SA Akademie vir Wetenskap en Kuns. 1993.

\section{OPENBARE OPTREDES, DEELNAME}

8.1 BUITELANDSE STUDIE EN NAVORSING

1. Studie: Vrije Unviersiteit Amsterdam. 1969 - 1970. Nederland (1 jaar).

2. Studiebesoek aan verskeie universiteite. 1972. VSA (2 maande).

3. Gereelde studie en navorsing vir korter tydperke in hoofsaaklik Londen en Amsterdam gedoen.

8.2 DEELNAME AAN BINNELANDSE KONFERENSIES

Verskeie referate is gelewer sedert 1973 op vakkonferensies van hoofsaaklik, die SA Historiese Vereniging en die Historiese Genootskap van SA.

8.3 DEELNAME AAN INTERNASIONALE KONFERENSIES

Ongeveer 20 voordragte is sedert 1990 gelewer op buitelandse vakkonferensies. 


\section{Tribute to Prof Pieter de Klerk}

Prof. Pieter de Klerk (65), subject head of History in the Faculty of Humanities on the Vaal Triangle Campus of North-West University (NWU, retires at the end of December 2011.

Part of this edition of TD The Journal for Transdisciplinary Research in Southern Africa is dedicated to the memory of a colleague who has made a deep academic mark in NWU. Over a period of 44 years he experienced much and got to know many people. He also became renowned. Although he tried in in a modest and sometimes unobtrusive way to pass through the corridors and chambers of the university, all and sundry were aware of his love for knowledge and more insight. As an academic he had an influence in shaping the intellect of many under- and post-graduate students.

He also had a spiritually enriching influence on colleagues. The editorial management of TD asked colleagues in the subject of History at several South African universities to contribute articles in this edition of the journal. Their contributions shed light on some of the areas of South African history in which Prof. De Klerk has a lively interest. Especially his interpretative articles on South African history and historiography are indicative of his broad spectrum of deep knowledge in which he has become a specialist. He consistently remained well informed and abreast of new trends in South African historiography. As peer reviewer of academic articles and active editorial member of several journals, amongst others, Historia, the official journal of the Historical Association of South Africa, he made valuable contributions.

For the purposes of this collection of articles, colleagues in the School of Basic Sciences at NWU were asked to contribute material. Also in the work presented here, Prof. De Klerk indirectly made a contribution.

Since the school concept was introduced at NWU in 1998, Prof De Klerk played a leading academic and administrative role. It required of colleagues to think anew on matters of academic management and how to turn departments into subject groups. It was all about 'flattening' structures to create a school system that would promote the integration of disciplines.

There were many chats in the tearoom of the School of Basic Sciences in the mornings. They left colleagues with many refreshing ideas. Prof. De Klerk was an active participant. He consistently played a pro-active role in serving the school director (currently Prof. TC Rabali) with sound advice. He also served in many faculty committees. His objective was constantly to improve efficiency and strive towards improving academic standards. Also in the faculty he served on many committees and made valuable contributions. His objective was to favour efficiency in the system and aspire to sound academic standards.

The disciplines currently (2011) forming part of the School of Basic Sciences include History, Biblical Studies, Philosophy, Public Management and Political Studies. Although Prof. De Klerk chose to busy himself with his beloved discipline of history, he liked to participate in discussions with colleagues in other disciplines. His sharp intellect and the ability to get to the essence of scientific thinking played a valuable role in the school. 
Over the years the interaction between colleagues, from different disciplines, had a marked effect on the manner in which the reality of daily academic activity was experienced. It also naturally influenced their research work. The variety of articles in this edition, tells of the spectrum of thought and ideas that circulate in a school of almost 20 members. As an academic Prof De Klerk sat in many colloquiums and research discussions of the School of Basic Sciences. By making comments and constructively criticising the work of colleagues he did them a great favour. Their contributions should be seen as a gesture of thanks to him. 


\title{
Hoe ons Pieter de Klerk sal onthou
}

\section{How we will remember Pieter de Klerk}

\author{
Kollegas van prof Pieter de Klerk aan die word \\ Colleagues of Prof Pieter de Klerk have their say
}

\begin{abstract}
Herinneringsbeeld van prof Pieter de Klerk se werksplek aan die Vaaldriehoekkampus van die Noordwes-Universiteit - Prof. Piet Prinsloo ${ }^{1}$
\end{abstract}

Prof Pieter de Klerk was sedert 1983 vir bykans dertig jaar 'n getroue deelgenoot in die wordingsjare van 'n universiteitskampus in die Vaaldriehoek. Oorsigtelik beskou, verdien die volgende aspekte vermelding in die vestiging van die Vaaldriehoekkampus in Vanderbijlpark.

Die Vaaldriehoekkampus het 'n beskeie begin gehad. Prof Albert Sorgdrager het gedurende 1963 op versoek van die plaaslike gemeenskap opknappingskursusse vir kosterekenmeesters in die Vaaldriehoek, in die handelskool, Lettie Fouché, se geboue, aangebied. Hierdie toetrede het tot gevolg gehad dat die Potchefstroomse Universiteit vir Christelike Hoër Onderwys (PUCHO) sedert 1966 'n na-uurse BCom-graad in die Vaaldriehoek aangebied het. Vir die aanbieding van die kursus het dosente vanaf Potchefstroom gependel. Sedert 1970 is na-uurse lesings vir 'n BA-graad in Vanderbijlpark aangebied. Prof SP van der Walt het in 1973 'n permanente kantoor in Vanderbijlpark vir die 385 na-uurse studente geopen. In 1976 is 'n vierverdiepinggebou in Goodyearstraat te Vanderbijlpark aangekoop en na-uurse lesings vir ' $n$ BSc-graad is begin. Gedurende 1979 het die na-uurse aanbieding van BEd- en HOD-klasse afgeskop. Dit verteenwoordig die vier studierigtings wat tot op hede aangebied word.

Die eerste tiental voltydse personeellede van die PUCHO wat gedurende 1976 en 1977 vanaf Potchefstroom na die Vaalrivierse tak gestuur is om 'n universiteitskampus te vestig, moes om die volgende redes teen die tydsgees in poog om 'n doelmatige universiteitskampus tot stand te bring.

Op nasionale vlak is die Randse Afrikaanse Universiteit (RAU) gedurende die sewentigerjare met genoegsame kapitaal en grootse vergesigte kragdadig gevestig. 'n Nuwe moderne universiteit het gevolglik 'n skrale sowat tagtig kilometer van die Vaaldriehoek verrys. Hiernaas het die destydse regering ook die aanbevelings van die Van Wyk de Vries-verslag ter harte geneem, wat beperkings op die verdere uitbreiding van die hoëronderwysinstellings aanbeveel het.

Die swart bevrydingsbewegings het boonop na 1976 se Soweto-opstande getoon dat die daeraad van swart nasionalisme aangebreek het. Die Vaaldriehoek het 'n onstuimige politieke klimaat beleef, wat onteenseglik aangetoon het dat die dae van eksklusiewe regte en voorregte vir bepaalde rasgroepe vir altyd verby was.

Op plaaslike vlak het die gemeenskapsleiers, sakelui en nyweraars die PUCHO se inisiatief geesdriftig gesteun om 'n satellietkampus in die Vaaldriehoek te ontwikkel, maar kon nie

1. Kampushoof/kampusrektor NWU (Vaal), 1995-2009.

Td The Journal for Transdisciplinary Research in Southern Africa, 7(2) December 2011, pp. xv - xxiii. 
genoegsame kapitaal monster om hierdie onderneming stewig te vestig nie. Die Vaalweekblad het, les bes, gereeld sy lesers aangemoedig om by die "kampus" op hul drempel te gaan studeer.

Op institusionele vlak het prof Hennie Bingle, die destydse rektor, 'n klein Gideonsbende benoem en op eg reformatoriese grondslag anngemoedig om hul roeping verder in die Vaaldriehoek te gaan uitleef. Gewapen met die karaktereienskappe wat die PUCHO oor tyd gekenmerk het, is die klein onderneming in die Vaaldriehoek in 1977 met sowat tien personeellede en 55 voltydse studente begin. Geld vir nuwe geboue was daar nie, want een universiteitskampus, die PUCHO, kon nie met die beperkte staatsubsidie 'n nuwe kampus ontwikkel nie. Geld vir bykomende personeel en nuwe programme, om vakkeuses te verruim, was daar ook nie. Personeel van die Potchefstroomkampus moes in dubbelskofte na die Vaaldriehoek pendel om hul kennis op Dinsdag- en Donderdagaande aan na-uurse studente oor te dra. Hierdie verdeelde lojaliteit het enersyds groot stremming op personeel geplaas. Andersins het die ontwikkelingskoste van die Potchefstroomkampus en die hoë vestigingskoste van die Vaaldriehoekkampus die Universiteit se begroting onder groot druk geplaas, wat menigmaal personeellede van die twee kampusse in uiteenlopende belangebotsings teenoor mekaar gebring het.

Gedurende 1983 is verdere momentum en bestuursoutonomie aan die ontwikkelende kampus gegee. Die kampus is na die Vaaldriehoekkampus herbenaam, met 'n viserektor as bestuurshoof, bygestaan deur adjunkdekane vir die vier subfakulteite wat aan die dekane op Potchefstroom gerapporteer het. 'n Volgende groep professore, waaronder prof De Klerk, is ook na Vanderbijlpark oorgeplaas om senioriteit aan die kampus se akademiese strukture te verleen. Die bouwerk op die rivierkampus het ook in die jaar 'n aanvang geneem. Die eerste professore in die Fakulteit Ingenieurswese aan die Vaaldriehoekkampus is ook in 1983 benoem.

In 1984 word die werksaamhede van die Vaaldriehoekkampus vanaf die Goodyearstraatgebou na die rivierkampus van 117 hektaar en nagenoeg $2 \mathrm{~km}$ rivierfront oorgeplaas. Die studentegetalle het in die jaar tot 1140 gestyg en die eerste gradeplegtigheid vir 99 graduandi is in die Vaaldriehoek gehou. Die Vaaldriehoekkampus se studenteraad het gedurende die jaar ook selfstandigheid van die sentrale studenteraad op Potchefstroom verkry.

Die Fakulteit Ingenieurswese het in 1987 die nuwe doelgemaakte geboue op die rivierkampus betrek. Die nuwe kampuskoshuise is in gebruik geneem en 'n huiskomiteestelsel vir koshuisstudente het in werking getree. Selfs op sportgebied het die nagenoeg 1848 studente vordering getoon. Die WATUNI's se eerste rugbyspan het die Presidentsbeker in die Vaaldriehoek gewen. Sportspanne het jaar na jaar op die suksesse voortgebou. In 1989 het die WATUNI-sportspanne ses uit die agt trofeë in die Vaaldriehoek verower.

Die jaar 1991 was 'n jaar van hoogdrama asook die vestiging van verdere akademiese strukture. Aan die negatiewe kant het die Fakulteit Ingenieurswese vanaf die Vaaldriehoekkampus na Potchefstroom verskuif en gevolglik die voorafgaande ontwikkelingsdrif getemper. Die studentegetalle het daarom tot 1587 gedaal. Aan die positiewe kant het die Universiteitsraad besluit om groter akademiese selfstandigheid aan die Vaaldriehoekkampus toe te ken. 'n Interfakultêre akademiese raad (IAR) is derhalwe gevorm wat soos ' $n$ fakulteitsraad in die senaat se werksaamhede gefunksioneer het. Die ampte van fakulteitshoofde in die plek van adjunkdekane vir die subfakulteite en departementshoofde vir departemente is ingestel wat direk an die viserektor as kampushoof gerapporteer het. Die 
ondersteuningsdepartemente het ook aan die viserektor gerapporteer.

Sedert 1995 het studente uit die agtergeblewe gemeenskappe met protesoptredes begin, wat die kampus se transformasieproses versnel het. 'n Voorbeeld van hierdie proses is die herbenaming en hergroepering van die koshuise vir dorpstudente. Die wit manskoshuis (Watuni) het saamgesmelt met die swart manskoshuis (Amabhubesi) en het die nuwe Oryxkoshuis gevorm. Die wit dameskoshuis (Ixia) het saamgesmelt met die swart dameskoshuis (Dishweshwe) en die nuwe Acacia-koshuis gevorm.

Hierdie transformasiedebat was nog volstoom op dreef toe die inkorporering van die VistaUniversiteit se Sebokengkampus met die Vaaldriehoekkampus van die PUCHO, op grond van die regering se herskikking van die hoër onderwys, in 2003 plaasgevind het. Sodoende het'n hele nuwe ontwikkelingsproses vir die kampus gevolg.

Die studentegetalle in 2003 was 2177 vir die Vaaldriehoekkampus en 629 studente vir Vista se Sebokengkampus, wat 'n totaal van 2806 studente meegebring het. Die akademiese personeelkomponent vir hierdie studente was 53 vir die Vaaldriehoekkampus en 20 vir Vista.

Die regering se transformasieproses van die hoër onderwys sedert 2004 het onder meer tot gevolg gehad dat die PUCHO en die Universiteit van Noordwes saamgesmelt het om die Noordwes-Universiteit te vorm. Gedurende 2004, die jaar van die samesmelting en inkorporering, het die Vaaldriehoekse studentegetal tot 3038 gestyg.

Op interpersoonlike vlak het die kampus baie studente se akademiese en romantiese drome beantwoord. Baie personeellede se professionele ontwikkeling en ervaring en die studente se akademiese vorming is genoegsaam op kampus geskool, sodat hulle gemaklik en suksesvol by ander instellings hul loopbane of studies voortgesit het.

Die Vaaldriehoekkampus as werksplek was ook deurentyd baie gewild. Dit het telkemale gebeur dat personeel wat om bepaalde redes bedank het, na 'n tyd weer vir werk aangeklop het. Die Vaaldriehoekkampus het as ontwikkelende kampus uitdagings aan sy personeelkorps gebied, wat op gevestigde kampusse ondenkbaar was. Hierteenoor het die Vaaldriehoekkampus as egte multikulturele kampus ook 'n reputasie onder studente en werkgewers opgebou dat studente uit verskillende volksgroepe, skouer aan skouer hul studies kon voltooi en sodoende 'n kultureel-sensitiewe leefervaring opgebou het wat vir sinvolle inskakeling in die werksplek noodsaaklik is.

In die tydperk 2004-2011 het die Vaaldriehoekkampus van die Noordwes-Universiteit ontwikkel tot 'n selfstandige en ware multikulturele universiteitskampus met 5601 studente, 154 permanente akademiese personeel, 150 permanente ondersteuningspersoneel, asook 'n hele aantal tydelike personeellede, wat ' $\mathrm{n}$ uitstekende reputasie as kwaliteitsgedrewe instelling in die hoëronderwyssektor losgewerk het.

Die Vaaldriehoekkampus is en bly 'n universiteitskampus wat, steeds getrou aan sy roeping, opleiding van 'n hoë gehalte lewer deur 'n toegewyde personeelkorps soos prof Pieter de Klerk. 


\section{Kollega-vriend - MF (Tienie) van der Walt ${ }^{2}$}

Mense leer mekaar ken en vriendskappe word gesluit op grond van gedeelde ervarings. My kontak met Pieter de Klerk strek oor 'n periode van ongeveer 47 jaar, waartydens ons baie ervarings gedeel het, van ons eerste jaar aan die PU vir CHO (1964) tot 20 jaar se saamwerk as kollegas by hierdie kampus. Daar is dus baie stof vir die oudag se "onthou-jy-noggesprekke". Dit is egter nie die ervarings as sodanig waaroor ek wil skryf nie, maar wel iets oor sy persoonlikheid wat ek deur hierdie ervaringe leer ken het.

Ek het aan verskillende begrippe gedink om Pieter mee te beskryf. Die vraag is, hoe beskryf mens iemand wat al op elke denkbare en ondenkbare plek op aarde was, maar nie 'n kamera besit nie? Hy liaseer sy prentjies in sy kop-kabinet! Hoe beskryf mens iemand wat 'n buitengewone kennis van nasionale en internasionele gebeurtenisse het, wat ' $n$ kenner is van al wat 'n gehalte-fliek is, wat sinvolle gesprekke kan voer oor byna elke nuwe publikasie van gehalte-fiksie, outobiografieë en reisverhale, maar hy besit nie ' $n$ TV nie en kan nie 'n selfoon gebruik nie? Hoe beskryf mens 'n hoogleraar in Geskiedenis wat die hoogste sport in sy beroep bereik het, maar pretensieloos is, geen waarde aan statussimbole heg nie, en nie enige nut sien in materiële ego-versterkers nie? Hoe beskryf mens iemand wat al die land per motor platgery het, en nooit besef het dat sy motor lugversorging het nie? Ek kon, na baie geskarrel met woorde, nie op 'n meer beskrywende begrip kom as "eksentriek" (in die positiewe sin) nie. Pieter de Klerk is eksentriek, want hy is in sekere opsigte uniek, anders, buitengewoon, a-tipies, onkonvensioneel en buitengewoon. Sy soort skop jy nie agter elke bossie uit nie!

Daar is nog ' $n$ ander begrip waarmee Pieter beskryf kan word, nl. "kwaliteit". Alles waarmee hy hom bemoei, getuig van kwaliteit-kennis, insig en begrip. Sy kennis van sy vakgebied is algemeen bekend. Sy kennis van gebeure van die dag, filosofiese en teologiese strominge, ens. het ons daaglikse teetyd-gesprekke gehalte gegee. As kenner van die jaarboek, samestelling van kurrikula, die A-reëls, Fakulteitsreëls, ens., het hy nie 'n gelyke op die kampus nie. Vir sommige sekretaresses is hy 'n pyniging, want hy sien elke tik en spelfout, elke foutiewe formulering en weglating raak. Baie lede van vergaderings sug as Pieter sy hand opsteek vir 'n spreekbeurt. Hulle wil die vergadering so gou moontlik afgehandel kry, maar Pieter onthou wat op vorige vergaderings besluit is, hy sien diskripansies raak en kyk krities na voorstelle wat ter tafel is. Al hierdie aktiwiteite spel vir my een woord, nl. "kwaliteit". Van vergaderings tot teekamergesprekke het Pieter ons verryk deur sy skerp vermoë tot kritiese denke.

'n Laaste kenmerk van Pieter wat my altyd sal bybly, is die feit dat hy nooit met 'n gekrenkte ego rondgeloop het as ' $n$ mens van hom verskil nie. Selfs na gesprekke wat af en toe driftig geword het, was die lug direk na die gesprek weer skoon. Ek het nooit kwade gevoelens of rugstekery ervaar na ' $\mathrm{n}$ intense woordewisseling nie. In my boek dui dit op ' $\mathrm{n}$ unieke integriteit.

Ek gaan Pieter mis, die kampus gaan hom mis, maar ek is dankbaar vir die baie jare wat ons 'n unieke kollega-vriendskap kon deel.

2. Afgetrede vakgroephoof Filosofie, Skool vir Basiese Wetenskappe, NWU (Vaal). 


\section{Vakman, leier en administrator - Dr Pieter Möller ${ }^{3}$}

Ek ken Pieter de Klerk sedert 1974 toe ek by hom klas gehad het as student in Potchefstroom.

Met my aanstelling by die Vaaldriehoekkampus in 1986 het ons paaie weer gekruis en het ek die voorreg gehad om as kollega in die department Geskiedenis saam met hom te werk tot 2011.

Op akademiese gebied het ek baie by Pieter geleer. Hy het gedurende hierdie jare meestal opgetree as vakhoof van ons department. Hy is 'n persoon met ' $n$ intensiewe vakkennis maar ook 'n geweldig wye algemene kennis. Ek het my altyd verstom an sy insig en gemaklike bestuurstyl. Pieter het nooit oor ' $\mathrm{n}$ mens se skouer geloer nie, maar jou altyd die kans en geleentheid gegee om jouself akademies uit te leef.

Pieter was in baie opsigte my mentor op akademiese gebied en sy deur het altyd oopgestaan vir enige insette wat van hom gevra is. Daarvoor het ek ontsettend baie waardering.

Akademiese administrasie was ook ' $n$ gebied waarop Pieter gespesialiseer het en hierin het hy ook spesiefke leiding geneem. Daar was nie ' $n$ reël in die boek wat hy nie geken het nie. Met my taak as fakulteitsbestuurder het Pieter my baie ondersteun en kon ek telkens na hom gaan indien ek onseker gevoel het oor 'n spesifieke saak. Hier het hy telkens die wysheid van Salomo aan die dag gelê.

Teekamer gesprekke was seker een van die mees verrykende ervarings. Hier het Pieter absoluut leiding geneem en is daar oor hoogs akademiese sake, maar ook ' $n$ wye reeks alledaagse gebeurlikhede gesels. Pieter kon oor rolprente, kultuursake, politieke vraagstukke en diesmeer ' $n$ waardevolle inset lewer tydens hierdie teekamer gesprekke. Sy insig oor soveel van hierdie sake het telkens respek by die ander teedrinkers ontlok. Sport was die enigste aspek waaroor Pieter nie graag gepraat het nie en sy standpunt was dat daar heeltemal te veel gemaak word van sport.

Ek het vir Pieter de Klerk as persoon die hoogste agting.

As kollega en akademiese vriend wens ek Pieter alles van die beste toe met sy aftrede. Ek is seker ons sal nog heelwat van hom hoor en dat hy ook in die jare wat kom nog ' $n$ daadwerklike bydrae sal lewer tot die vak geskiedenis.

\section{Honest and humble person ... speaking out ... on important matters - Prof. TC Rabali $^{4}$}

He has a good memory and is able to share his knowledge of the history of this institution with all of us. His retirement leaves a huge vacuum because in the School of Basic Sciences, the Faculty of Humanities, and in the campus senate, we depended on him to provide a historical context for the developments and issues we discuss.

He always participated in our school's colloquia and gladly shared his research insights. Prof De Klerk is an honest and humble person who does not shy away from speaking out his mind

3. Vakgroep Geskiedenis, Skool vir Basiese Wetenskappe NWU (Vaal).

4. Director, School of Basic Sciences, NWU (Vaal).

$T d, 7(2)$, December 2011, pp. xv - xxii 
on important matters. He is also very human as evidenced by the fact that he has been the anchor and host of our tea room discussions. Our debt to Prof De Klerk as School of Basic Sciences is also huge in that he helped to ensure that we made good and strategic appointments as we grew the school to what it has become. He served in our selection and interview committees together with me whenever we sought to fill any vacant position.

Our prayer is that God will continue to take care of Prof De Klerk during his retirement years so that he in turn will be a blessing to many (Psalm 71).

\section{Revered Teacher with historical wisdom - Prof. Shikha Vyas-Doorgapersad ${ }^{5}$}

Prof. Pieter De Klerk is a historian in intellect, an academic in excellence and a person of perfection. Listening to his insightful opinions and detailed understanding on topics of relevant interests can motivate other academics to go deeper into the ocean of knowledge and gather more enlightening pearls and didactic means that Prof. De Klerk has earned throughout his academic journey. His intellectual odyssey will always be considered as a foundational milestone for the scholars of the School of Basic Sciences as an inspirational force for literary revelation and knowledge elucidation. The young academics and emerging researchers salute his legendary personality, moreover his comprehensive awareness and realization, as a Revered Teacher with historical wisdom.

\section{Gespreksgenoot in die teekamer - Dr Ina Gouws ${ }^{6}$}

Ek het as nuwe dosent by die Vaal kampus aangekom in 2003. Daar is vroeg vir my gesê dat 10:00 in die oggend tee-tyd is en dat dit bykans verpligtend is. Min het ek geweet...

Soos die jare aangegaan het, het mense tee-tyd begin mis en die meerderheid van die mense in die skool het dit maar bygewoon soos wat hulle tyd en lus gehad het.

Nie ek nie. Prof de Klerk kom haal my en kollega Herman van der Elst uit ons kantore uit elke more 10:00! Ek het begin wonder hoekom ek dan nou so verplig word, maar het besef dat dit eintlik ' $n$ groot kompliment is.

Gesprekke in die teekamer met Prof. de Klerk gaan oor enigiets van geskiedenis en politiek tot teater, films en boeke. En ek het besef hy sal jou slegs uit jou kantoor kom haal as jy jou geselskap geniet en geïnteresseerd is in wat jy te sê het.

So dit is met groot dankbaarheid dat ek elke dag met graagte teekamer toe gaan. Ek het so baie uit my gesprekke met Prof. de Klerk geleer en selfs wanneer ons verskil het van opinie, kon ek nie help om tog sy wysheid na die tyd te erken nie.

Ek gaan hom mis. Dis al.

5. Associate Professor, Public Management and Administration, School of Basic Sciences, NWU (Vaal).

6. Senior lektor, Politieke Wetenskappe, Skool vir Basiese Wetenskappe, NWU (Vaal). 


\section{Die blywende indruk - Willie Luyt ${ }^{7}$}

Voordat ons van Prof afskeid neem sou ek graag wou sê dat jy 'n blywende indruk op my as akademikus gemaak het in die voorbeeld wat jy vir ons gestel het as $n$ kritiese denker. Jou wye algemene kennis en akkuraatheid met taalgebruik het my altyd beïndruk. Die werk wat Prof gedoen het op bestuursvlak om Afrikaans as onderrigtaal behoue te laat bly asook die prossese om die kwaliteit van navorsing hoog te hou, sal altyd onthou word.

$\mathrm{U}$ insette sal terdeë gemis word.

Ek wens u 'n voorspoedige en geseënde aftrede toe.

\section{'n Lojale persoon - Me Debbie McCallum ${ }^{8}$}

Prof Pieter sal ek altyd onthou as 'n persoon wat geneig is om 'n introvert te wees en met die wêreld se kennis in pag sit. Hy is 'n baie lojale persoon. Wat ek nogal baie waardeer het oor wat hy doen, was sy fondasie "back to basics" en werk van daar af deur die sisteem. Dit was altyd 'n baie goeie riglyn om van te werk.

\section{Merci Pieter de Klerk - Dr MT Lukamba ${ }^{9}$}

Je connue professeur Peter de Klerk l'année passe quand je commence ma carrière académique au département de la gestion public ici au Campus de Vaal Triangle. C'est un bon collègue que je beaucoup apprécie sur le plan scientifique. C'est un model que nous devons suivre pour arrive au niveau qu'il est arrive jusque a la fin de sa carrière académique. Je vous souhaite un très bon repos pendant ta pension à la ville du Cap.

Merci.

\section{My humble parking colleague - Prof. Ernest Ababio ${ }^{10}$}

Prof Pieter de Klerk assumes a senior citizen role in that he championed socialization of colleagues by tearoom chats. Never did he miss it. A principled colleague, never did Pieter as well miss his yearly 3-month research tour of the Netherlands. If he had a point to prove, he would close his ears to alternative views and put his case across, sometimes emotionally. Pieter is learned, resourceful, a good listener, and sympathetic. I will miss him as a humble parking colleague.

7. Vakvoorsitter, Filosofie, Skool vir Basiese Wetenskappe, NWU (Vaal).

8. Sekretaresse, Skool vir Basiese Wetenskappe, NWU (Vaal).

9. Senior lecturer, Public Management and Administration, School of Basic Sciences, Faculty of Humanities, NWU (Vaal)

10. Chair: Public Management and Administration, School of Basic Sciences, Faculty of Humanities, NWU (Vaal). 


\section{'n Groot wilger in die PUK-tradisie - Dr Herman van der Elst ${ }^{11}$}

In die ontwikkeling van my akademiese loopbaan is daar sekere mense wat ek as 'n mentor beskou. Professor Pieter de Klerk is een van daardie mense. Ek ken vir Pieter sedert 2006 toe ek by die Skool vir Basiese Wetenskappe aangestel is. Pieter is ' $n$ gevestigde en deurwinterde akademikus waarvoor ek baie respek het. In die PUK-tradisie is hy waarlik 'n groot wilger.

In die ses jaar wat ek saam met hom gewerk het, het ek derhalwe baie by hom geleer. Wat ek altyd van hom sal waardeer en respekteer is sy vaste beginsels rakende die dinge waarin hy glo, en die waarde wat hy aan akademiese standaarde heg. Vir hom is daar geen plaasvervanger vir akademiese standaarde nie as dit kom by klasgee, begeleiding van nagraadse studente, navorsing of die skryf van artikels nie. Vir ons jonger mense het hy in hierdie verband altyd 'n stewige voorbeeld gestel waarop ek net kan voortbou en as voorbeeld gebruik in my eie loopbaan en ontwikkeling van my vakdissipline.

Ook het ek baie waardering vir sy fyn (Nederlandse) humorsin en breë algemene kennis. Dit het gelei tot baie interresante teekamergesprekke.

In bogenoemde verband sal Pieter se akademiese kwaliteite, maar veral Pieter as mens gemis word in die skool.

Pieter alles van die beste vir die toekoms.

\section{Tsamaya hantle Moprofesara Pieter De Klerk - Dr Tumi Mzini ${ }^{12}$}

Ke hopola ha ke ne ke tlile dipotsong tsa mosebetsi (job interview) wa bolecturer, ka selemo sa July 2007. E ne re ke botswa potso, mme ke ne ke tshwanetse ho etsa mohlala ka mosebetsi waka. Ke ile ka qolla lebitso la Oom Piet, ke maketse ha batho ba ile ba keketeha ke ditsheho, ka nako eo ke ne ke sa elellwa hore monga lebitso o teng ka phaphusing eo. Ke kgolwa o ile wa utlwisisa polelo yaka ka motsoso ono.

Mehla le mehla ha re le dikopanong, e tlare ha ho bolelwa ditaba, ke rata ho sheba ka ho wena, hobane o tla tsitsinya hloho mme o hanane le ditaba tse bolelwang. Mme re tla tsheha re keketehe hobane o dula o re tshehisa ka dinako tsohle. Sena se nkgopotsa mohla re ne re bontshana ka letsatsi la botjhaba (Heritage Day celebration) ka selemo sa 2009. Letsatsi la phomolo le ne le tla ba ka moqebelo, mme wena o ile wa sisinya hore le rona re tlameha ho keteka ka moqebelo, hobane e le letsatsi la sebele.

Ke rata hore ho wena Prof, pele ya pele ntate, o mohlala ho rona. Dilemong tsa hao, batho ba bangata ba a kgathala empa wena o ntse o le dibukeng. Ke ithutile tse ngata ho wena. E ka re Morena Modimo o ka o baballa o fetisetse mpho ya thuto ha bana ba rona. Ke hore bake ba bone hore ditho ke lefa.

Re lebohela tshwarello ya hao mosebetsing wa NWU. E ka o ka phomola ha monate lapeng moo. Re tla o hoopla Prof P De Klerk.

11. Vakgroephoof Politieke Studies, Skool vir Basiese Wetenskappe, NWU, (Vaal).

12. Senior lecturer, Public Management and Administration, School of Basic Sciences, NWU (Vaal). 


\section{Pieter de Klerk in gesprek met Td}

Die redaksie van TD Die Joernaal vir Transdissiplinêre Navorsing in Suider-Afrika het met prof. Pieter de Klerk gesprek gevoer om sy mening oor 'n klompie relevante sake in sy lang loopbaan aan Noordwes-Universiteit te kry.

$T d=$ Redakteur $\mathrm{Td}$

$\mathrm{PdK}=$ Pieter de Klerk

$T d$ : As historikus het jy oor 'n tydperk van 44 jaar in die akademie waarskynlik meer veranderinge en omskakelings in die dissipline van geskiedenis as meeste historici ervaar. Wat was die uitstaande tendense in die dissipline?

PdK: Die geskiedeniswetenskap bestryk ' $n$ wye terrein en ek is beslis nie 'n kenner van alle onderafdelings van die vak nie. Ek het my aanvanklik toegespits op die Europese geskiedenis, in besonder op die vroeg moderne tydperk. In die 1960's is daar aan die meeste SuidAfrikaanse universiteite feitlik ewe veel aandag aan Europese en Suid-Afrikaanse geskiedenis gegee. Toe eers is begin om Afrikageskiedenis deel van die sillabus te maak. Soos aan Amerikaanse en ook sommige Europese universiteite is daar in Suid-Afrika weg beweeg van ' $n$ Eurosentriese benadering en is daar onder andere meer aandag gegee aan die geskiedenis van Asië. Tans is inleidende kursusse in wêreldgeskiedenis ' $n$ algemene verskynsel aan universiteite oor die wêreld heen. Aan Suid-Afrikaanse universiteite is die plek wat aan die geskiedenis van die wêreld buite Afrika in sillabusse toegeken word egter dikwels besonder klein. Die impak van globalisasie bring mee dat ' $n$ breë begrip van die wêreldgeskiedenis, veral van die afgelope twee eeue, meer noodsaaklik is as ooit tevore. ' $\mathrm{n}$ Mens hoop dat wêreldgeskiedenis ' $n$ groter plek in toekomstige Suid-Afrikaanse universitêre onderrig sal beklee. Die tendens om te fokus op besondere temas of subdissiplines, soos omgewingsgeskiedenis of gendergeskiedenis, het waarskynlik in die afgelope dekades toegeneem. Dit kan ' $n$ positiewe ontwikkeling wees as dit nie lei tot verwaarlosing van die breë historiese vorming van studente nie.

Wat die Suid-Afrikaanse geskiedenis betref, het ek veral navorsing gedoen op die terrein van die historiografie. Voor 1960 was daar maar min Afrikaanse historici en slegs enkeles onder hulle het buite die Afrikaanse kring bekend geraak. Een van hulle was die Potchefstroomse historikus D.W. Krüger. Sy boek The age of the generals (1958) was die eerste belangrike sintesewerk oor die ontwikkeling van die Unie van Suid-Afrika voor 1948, en Afrikaans- en Engelstalige wetenskaplikes het hoë waardering daarvoor gehad. In die sestiger- en sewentigerjare was daar groot geskiedenisdepartemente aan Afrikaanse universiteite, en Afrikaanse geskiedkundiges is aangestel aan universiteite wat in hierdie jare vir die swart, bruin en Indiërbevolkingsgroepe opgerig is. Die toename van Afrikaanse historici het egter nie gelei tot betekenisvolle bydraes ten opsigte van meer as enkele aspekte van die SuidAfrikaanse geskiedenis nie. Afrikaanse historici het bly konsentreer op konvensionele politieke geskiedenis, en veral op die geskiedenis van die Afrikaner. Met die moontlike uitsondering van F.A. van Jaarsveld het geen Afrikaanse historikus met vernuwende geheelinterpretasies van die Suid-Afrikaanse geskiedenis, vergelykbaar met C.W. de Kiewiet se $A$ bistory of South Africa; social and economic (1941), na vore gekom nie. Die Engelstalige historici van die sogenaamde liberale en radikale skole het die algemene rigting waarin die

TD Die Joernaal vir Transdissiplinêre Navorsing in Suider-Afrika, 7(2) Desember 2011, pp. xxiii - xxvii. 
Suid-Afrikaanse geskiedskrywing beweeg het bepaal. Sedertdien het die getal geskiedenisstudente en daarmee ook die getal Afrikaanse historici steeds kleiner geword. Afrikaanse historici neem tans ' $n$ beskeie plek in binne die ontwikkeling van die SuidAfrikaanse geskiedskrywing. In die afgelope dekades het eintlik net een Afrikaanse historikus, Hermann Giliomee, hom gevestig as ' $\mathrm{n}$ internasionale leiersfiguur onder die geskiedskrywers oor Suid-Afrika.

Td: Baie mense redeneer dat die tyd van geskiedenis, en in die besonder die geesteswetenskappe, is aan die verbygaan. Reken jy werklik dat geskiedenis as universiteitsvak tot niet sal gaan?

PdK: Nee, beslis nie. Vanaf die vroegste tye het mense belanggestel in hul geskiedenis en geskiedeniswerke geskryf. Denkrigtinge waarin geskiedenis as van minder belang geag is, het in die afgelope eeue soms 'n groter en soms 'n kleiner invloed in wetenskaplike kringe gehad. In die huidige tydsgewrig is daar waarskynlik baie tegnokrate en ook wetenskaplikes wat nie veel waarde aan geskiedenis en ander geesteswetenskappe heg nie. Tog is daar nog baie studente, in al die wêrelddele, wat geskiedenis as 'n universiteitsvak neem en verskyn daar voortdurend wetenskaplike publikasies op alle terreine van die geskiedkunde. In Suid-Afrika word daar tans besondere klem geplaas op die opleiding van mense met natuurwetenskaplike en tegniese vaardighede asook op direkte voorbereiding vir beroepe. Daar is ' $n$ insinking in die belangstelling in geskiedenis en ander geesteswetenskappe. Ook in Suid-Afrika sal daar egter altyd mense wees wat meer van die geskiedenis van hul gemeenskap en hul land wil weet. Hopelik sal daar weer 'n oplewing in die bestudering van geskiedenis as universiteitsvak kom.

$T d$ : Jy het ' $n$ lang geskiedenis van belangstelling in veral die Kaapse geskiedenis. Wat is vir jou die belangrikste ontwikkeling op die terrein in onlangse jare?

PdK: R Elphick en H. Giliomee se The shaping of South African society, waarvan die eerste uitgawe in 1979 verskyn het, het die bestudering van die geskiedenis van die Kaapkolonie gestuur in die rigting van ' $\mathrm{n}$ ondersoek na rasseverhoudinge en die wortels van rassediskriminasie in die periode voor 1850. Daar is heelwat navorsing gedoen oor slawerny, gedwonge arbeid en onderdrukkende praktyke deur die koloniste en die koloniale owerheid. Dit lyk tans of daar ' $n$ verskuiwing van ' $n$ sosiaal-ekonomiese na ' $n$ sosiaal-kulturele perspektief plaasvind en meer aandag gegee word aan die leefwyse van die koloniste as wat in die afgepe paar dekades die geval was. Dit is opmerklik dat van die belangrikste studies oor die vroeë Kaapse geskiedenis deur buitelanders geskyf is en dat in Suid-Afrika die meeste navorsingswerk op hierdie terrein tans aan die Universiteit van Kaapstad gedoen word. Die Universiteit van Stellenbosch en ook die Universiteit van Wes-Kaapland se bydraes tot hierdie navorsing is maar beskeie.

Td: Na alle waarskynlikheid is jy seker aan van die dosente wat die langste aan NoordwesUniversiteit vertbonde was. Vertel asb. een en ander van jou lewe eers op die Potchefstroomse kampus en later op die Vaaldriehoek. 
PdK: As ' $n$ mens terugkyk, lyk die vroeë jare na 'n goue era vir akademiese personeel. Daar was toe nog geen sprake van taakooreenkomste, studiegidse, memorandums en evaluerings van doseerwerk nie. Daar was ook geen geakkrediteerde tydskrifte nie, en in Suid-Afrika het redakteurs van vaktydskrifte in die geesteswetenskappe gewoonlik alleen besluit oor die plasing van artikels. ' $n$ Mens kon elke ses jaar lang verlof neem sonder dat jy na die tyd moes verduidelik wat jy gedoen het. Daar was tog ook negatiewe dinge. By die bevordering van akademici was senioriteit die vernaamste faktor; iemand is selde bevorder bo die posvlak wat 'n meer senior persoon in die departement beklee het. Publikasies is by bevordering byna nie in ag geneem nie.

Ek is al vanaf 1971 by die Vaaldriehoekkampus betrokke, toe daar begin is om na-uurse klasse vir BA-studente daar aan te bied. Daar het byna elke weeksaand groepe dosente tussen Potchefstroom en Vanderbijlpark gereis. Toe ek in 1983 na die Vaaldriehoek geskuif het, was die personeel in ' $n$ paar geboue in die noordelike deel van Vanderbijlpark gehuisves. Die terrein waarop die kampus tans is, was toe al in besit van die universiteit en daar is begin om 'n struktuur op te rig wat as tydelike gebou vir die ingenieursfakulteit moes dien (die huidige administrasiegebou). Voor die bouwerk voltooi is, het die universiteitsbestuur egter van plan verander en is die gebou aan die dosente in die geesteswetenskappe toegewys terwyl die ingenieurs in die ou geboue agtergebly het. In die nuwe gebou moes van my kollegas jare lank half oop ruimtes as kantore gebruik. In 1991 is besluit om die ingenieursfakulteit na Potchefstroom te verskuif en het die geesteswetenskaplikes weer eens ingetrek in geboue (die huidige geboue 4 en 7) wat vir die ingenieursfakulteit ontwerp is.

Ek het aangename herinneringe aan die kontak wat ek oor die jare met kollegas, veral ook van ander vakke, kon hê. In die 1970's was die grootste deel van die fakulteit Lettere en Wysbegeerte op Potchefstroom in die Frans du Toitgebou gehuisves en het dosente van ' $n$ verskeidenheid dissiplines mekaar geken en ook oor akademiese sake gesprek gevoer. By die Vaaldriehoekkampus was die situasie in die tagtigerjare baie soortgelyk. Hierdie kampus het voortdurend gegroei en ongelukkig is kontak met kollegas tans feitlik beperk tot diegene wie se kantore nie net in dieselfde gebou nie, maar ook op dieselfde vloer is. Met my kollegas van die Skool vir Basiese Wetenskappe (op die tweede verdieping van gebou 4) vind daar egter nog baie goeie gesprekke in die teekamer plaas.

Te midde van politieke woelinge in die land, het die $\mathrm{PU}$ vir $\mathrm{CHO} / \mathrm{NWU}$ steeds ' $\mathrm{n}$ stabiele en rustige werksomgewing gebied. Daar is wel voortdurend nuwe vereistes gestel waaraan akademici moes voldoen, maar hierdie veranderinge het meesal geleidelik geskied. Oor die algemeen was daar ' $n$ aangename werksklimaat in die departemente, skole en fakulteite waarvan ek deel was. Dit het daartoe bygedra dat die 44 jaar vir my vinnig verbygegaan het.

$T d$ : Jou betrokkenheid by die universiteitswese was nie altyd uitsluitlik by die vakgebied nie. Jy was baie betrokke by samesprekinge in menige vergaderings oor die ontwikkeling van veral die Vaaldriehoekse kampus van NWU. Het jy enige herinneringe aan wat daaroor gepraat is en hoe dit later verwesentlik is?

PdK: In die tagtigerjare was daar ' $n$ argiteksmodel in die voorportaal van die (huidige) administrasiegebou waarvolgens daar vir ' $n$ groot aantal geboue op die kampusterrein voorsiening gemaak is. Daar is aanvanklik aanvaar dat die Vaaldriehoekkampus sou uitgroei tot 'n aparte universiteit en later dat dit 'n groot universiteitskampus sou word, maar hierdie verwagtinge moes in die tagtigerjare afgeskaal word. Vreemd genoeg is daar tot lank na 1980 
steeds net in terme van Afrikaanssprekende blanke studente gedink. Ek onthou vergaderings waar besluit is om weg te doen met die oorspronklike beplanningsmodel vir die kampus, om swart studente toe te laat en om ' $n$ parallelmediumstelsel met klasse in beide Engels en Afrikaans in te voer. Hiermee het die Afrikaanse karakter van die kampus in ' $\mathrm{n}$ meer multikulturele karakter verander. Die Afrikaanse komponent het egter steeds ' $n$ kernelement van die multikulturele opset gebly. Daar is tans nog heelwat Afrikaanse studente en personeellede en daar is geen rede waarom daar binne afsienbare tyd ' $n$ drastiese verandering in hierdie verband moet plaasvind nie. As diegene wat die kampus in ' $n$ eentalig Engelse rigting wil stuur hul sin kry, sal dit myns insiens ' $n$ negatiewe invloed op die kulturele verskeidenheid en daarmee op die unieke karakter van die kampus hê.

Tot in die 1990's het akademiese bestuurders van die Potchefstroomkampus toesig oor die werksaamhede aan die Vaaldriehoek gehou. In die negentigerjare was daar vergaderings van akademici wat die kampus verteenwoordig het, maar waar ook vier dekane van Potchefstroom aanwesig was wat nie geskroom het om ons te vermaan waar nodig nie. Die samesmelting met die Universiteit van die Noordweste in 2004 het as 'n onverwagte gevolg groter selfstandigheid vir die Vaaldriehoekkampus meegebring. Met die groei van die afgelope jare lyk dit nou tog of die ideaal van 'n groot kampus wat 'n wye spektrum van vakke aanbied verwesenlik word.

$T d$ : Jy het heelwat navorsing en skryfwerk oor die geskiedenis van die universiteitswese gedoen. Wat reken jy is die toekoms van die universiteitswese in Suid-Afrika? Is die NWU darem op koers?

PdK: Ek wil my nie oor die universiteitswese in Suid-Afrika in die algemeen uitlaat nie. Wat die NWU betref, is daar vir my te midde van al die positiewe ontwikkelinge tog ook sake wat rede tot kommer gee. Die proses om die onderrig vir die grade wat aan twee of al drie kampusse aangebied word te belyn, het ' $n$ tendens voortgesit wat, veral as dit nog verder gevoer word, nadelig vir akademiese ontwikkeling sal wees. Wanneer dosente op drie kampusse dieselfde modules moet aanbied en dieselfde studiegidse gebruik, word daar weinig ruimte gelaat vir akademici om hul eie oordeel en inisiatief te gebruik wanneer hulle hul doseertaak verrig. As akademiese personeellede aan die begin van hul loopbaan ervaar dat baie besluite, onder meer rakende doseerwerk, vir hulle geneem word en dit vrugteloos sal wees om hierdie besluite te bevraagteken, kan dit daartoe lei dat hulle aanvaar dat daar ook vir hulle gedink word en strem dit hulle ontwikkeling as selfstandige wetenskaplike denkers. Die ontwikkeling van die wetenskap berus juis daarop dat voortdurend vrae gevra word en geen standpunte bloot aanvaar word omdat diegene wat die standpunte huldig met bepaalde gesag beklee is nie. Dit is ' $n$ wêreldwye tendens dat universiteite al meer soos sake-ondernemings bestuur word, maar daar is ook oor die wêreld heen akademici wat besef dat akademiese vryheid, en daarmee saam die ontwikkeling van die wetenskap, hierdeur bedreig kan word en dat sulke nadelige gevolge ten alle koste voorkom moet word. Ek is seker dat daar ook aan die NWU persone is wat van hierdie probleme bewus is en iets daaraan probeer doen.

$T d$ : Wie was van die uitstaande persoonlikhede aan NWU van wie jy steeds herinneringe het?

PdK: In die 48 jaar sedert ek as 'n eerstejaarstudent aan die PU vir $\mathrm{CHO}$ begin studeer het, het die universiteit net vier rektore/visekanseliers gehad, naamlik proff. H.J.J. Bingle, T. van 
der Walt en C.J. Reinecke en dr. T. Eloff. Ek het nie met een van hulle veel direkte kontak gehad nie, maar elk van hulle het in die lang termyn waarin hy aan aan die stuur van sake was ' $n$ besondere stempel op die universiteit afgedruk. Die ontwikkeling van die universiteit in hierdie jare, en ook my eie ervaring daarvan, is in die eerste plek met hierdie persone verbind. Hierbenewens was daar verskeie akademici, meesal leermeesters in my studentejare, wat ' $n$ groot indruk op my gemaak het. Ek dink veral aan die twee historici D.W. Krüger en J.S. du Plessis. Ek het net as ' $n$ voorgraadse student by prof. Krüger klas gehad. Daar was toe reeds talle staaltjies oor hom in omloop. Hy was beslis ' $n$ kleurvolle persoonlikheid wat baie gedoen het om my, en waarskynlik baie ander, se belangstelling in die geskiedenis aan te wakker en te versterk. Op nagraadse vlak was prof. Du Plessis my vernaamste dosent, en ook my studieleier en promotor. Hy het my nie in 'n bepaalde rigting probeer dwing nie, en was as historikus baie ruim denkend. Hy het verder op 'n simpatieke wyse akademiese leiding verskaf. Hierdie persoonlikheidseienskappe het dan ook seker daartoe gelei dat hy later dekaan en viserektor geword het.

$T d$ : Ofskoon jy, soms onder protes, van nuwe tegnologie begin gebruik gemaak het in die beoefening van jou beroep as historikus, het jy indertyd met groot vaardigheid daardie tegnologie wat vir jou doeleindes van pas was, onder die knie gekry. Jy het dit ook goed beheer. Watter van hierdie tegnologieë het jy tot dusver die meeste baat by gevind?

PdK: Van al die aanpassings wat ek gedurende my loopbaan moes maak, was die verwerwing van die nodige rekenaarvaardighede waarskynlik die moeilikste. Ek het die gebruik van die nuwe tegnologie maar net in baie beperkte mate bemeester. Tog is dit nou vir my moeilik om in te dink hoe ek vroeër sonder 'n rekenaar my proefskrif, artikels, ensovoorts, geskryf het. Naas die woordverwerkingsprogram is die internet 'n hulpmiddel waarsonder ek seker nie meer sal kan klaarkom nie. 